\title{
Fronteras Imaginarias: Theorizing Fronterizidad in the Simulated Illegal Border Crossings of El Alberto, Mexico
}

\section{Natalie Alvarez ${ }^{1}$}

“Oye, Gloria, aguantaras hasta California?” ("Hey, Gloria, can you make it to California?"). I was expecting the significance of this tourist's question to be diffused by nervous laughter, as we crouched, huddled along a dusty path in amongst brush in the dead of night with little moonlight and only our coyote to guide us. The question, instead, was met with awkward silence as we tried to catch our breath. Two hours into this night trek through the desert canyon of El Alberto, Mexico in the heart of the Valle del Mezquital — with our field of vision limited to the person next to us, but imaginatively reaching all the way to the border some seven hundred miles north of the site of this fictional border crossing - the prospect of "making it" "for real" is, in fact, unimaginable. This question, "Can you make it to California?" uttered in the context of this simulated border crossing was an invitation - or perhaps a reminder-for all of us tourists huddled there to immerse ourselves "in the role" of illegal migrant and to try to amplify in our imaginative vistas - by hours, by degrees of hunger, thirst and fatigue, by levels of fear, injury, and threat - this mere fragment of an experience into the kind of journey that it might be, or could be, "for real." In the time that has passed since this caminata nocturna, or "night walk" as the simulation is called, the question, "Can you make it to California?" remains there in that silence both awkwardly and ominously, a hollow echo of a question undoubtedly uttered in desperation by some of the roughly 600,000 plus migrants who attempt to cross illegally into the United States every year. ${ }^{2}$

If we think of the border as an interpellating force that hails and constitutes the identities to whom it grants passage or expels, a regulatory force that has come to constitute transnational migrant identities and fronterizas/os in movement across national boundaries, then what constitutive acts take place in a reenactment of this passage? How does a reenacted border crossing lay bare the performative force of the border? Furthermore, in this laying bare what questions does it compel us to ask about the construction of cultural identities made in the image of what Marcial Gonzalez refers to as "the most repressive and racist symbol of demarcation and exclusion produced by capitalism, nationalism, and imperialism-namely, the

Natalie Alvarez is an assistant professor at Brock University's Department of Dramatic Arts, where she teaches in the theatre praxis concentration. She has two edited books (forthcoming) on Latina/oCanadian theatre and performance with Playwrights Canada Press and is currently working on a SSHRC-funded manuscript project titled Enactments of Difference: Simulation and Performance from Military Training to Dark Tourism. 
border"'? ${ }^{3}$ 'd like to situate the simulated border crossing in El Alberto, Mexico, as a social imaginary and praxis - that is, as a repertory of collective practices and symbolic representations with material impacts on the community - that not only constitute cultural identities but also develop a critical realism seeking to dismantle, paradoxically, the very borders that constitute them. ${ }^{4}$

The caminata nocturna takes place every Saturday night at the Parque EcoAlberto - an adventure tourism park run by the indigenous community of the Hñahñu in the municipality of Ixmiquilpan, Hidalgo, roughly three hours north of Mexico City. The rugged valley that surrounds the park's site, thick with cacti and bushes, swamp, and steep, rocky climbs, becomes the obstacle course for a largely improvised game in which some eighty-two members of the Hñahñu community take on a variety of roles in the simulation. These community members play either the coyotes (or polleros), guiding the tourists who have paid roughly twenty US dollars each for this five- to seven-hour journey, or the US border patrol, undermining the performative power of the oppressor in an instance of Boalian Theatre of the Oppressed. ${ }^{5}$ As these "border patrol officers" chase participants in police cars, they use a range of good cop/bad cop techniques to try to lure them out of hiding: firing gunshots in the air, roughhousing and arresting a captured member of the group, or, in the broken, gringo Spanish of American border police, reasoning with participants to abandon their dangerous mission. ${ }^{6}$ Other members of the community are integrated into the group of tourists-as-migrants to play the role of captured migrants, who are tackled, thrown onto the hood of the patrol car, handcuffed, humiliated, and removed. ${ }^{7}$ It would be perverse to call the Hñahñu method actors, but as Jose Perez Cruz, one of our coyotes, or "guides," tells me after we conclude the caminata, the representations in this reenactment are based on their own firsthand, lived experiences crossing the border - a journey that roughly ninety percent of the male members of the community have undergone. ${ }^{8}$

The ingenuity of this simulation attests to the impact of the immigration crisis upon a community seeking to mitigate its effects through reenactment. Through this reenactment, the Hñahñu have turned the very crisis responsible for the dissolution of their community - the migration of mostly male members of their community to the US - into a source of profit and a means of building an autonomous infrastructure and industry for the communal town. ${ }^{9}$ When I press Jose to tell me who is responsible for this idea, he replies, "The community - the community thought of it," a reply that reveals a commitment to alliance and communality that leaves me feeling like the interrogating peninsular to his Fuenteovejuna. The reenactment can, perhaps, be thought of as the community's pharmakon, representing both the curse of the necessity of migration and the potential cure of its ritualized reenactment, which forestalls and undoes both the imaginative hold of the border and eventually, as their tourist site and local industry grows, the necessity to reach it. ${ }^{10}$ While paying tribute to the transnational identities of migrants which the border crossing interpellates, 
this reenactment every Saturday evening is also, paradoxically, a performative enunciation of "el derecho de no migrar" ("the right not to migrate"). ${ }^{11}$

The Parque EcoAlberto has grown largely through a community arrangement of volunteer work, known as faenas, in which community members take turns working on community building and development projects without pay for a year. When they are not contributing directly to the community through faenas, most men - and a minority of the women - seek work across the border in the US, generating not only remittances that aid in stimulating the community's development, but also an income that will subsidize the unpaid year of volunteer labor. ${ }^{12}$ But the development of Parque EcoAlberto as a tourist destination has also been fostered by Escuela Bancaria y Comercial, a business school in Mexico City that builds partnerships with neighboring communities to enfranchise and stimulate local economies through tourism. The dean of the business school, Javier Prieto Sierra, returned to the site with family members and friends to celebrate the site's fifth anniversary and conveyed his enthusiasm for the evident success of the partnership that has encouraged an autonomous, local economy to take shape. But the significance of the border crossing reenactment in the face of the broader horizon of the Hñahñu - a community still defined, for the moment, by its reliance on migrant labor-was not lost among his companions, one of whom asserted that "members of homeland security should be made to take this journey."13

The community's first caminata nocturna was inaugurated in July 2005, five months before the US House of Representatives passed HR 4437, the Border Protection, Anti-Terrorism, and Illegal Immigration Control Act in an effort to lock-down borders. Perhaps due to its timely inauguration, the simulation became a barometer for the climate of border hysteria in the United States. Legible through the wave of alarmist press reports, this "border crossing theme park" was seen as a training ground for prospective illegal immigrants with minimal mention of the indigenous community or the communal rebuilding efforts motivating the tourist attraction. An ABC online headline, for example, sensationally reads, "EXCLUSIVE: Border Crossing Training Ground or Vacation Destination?" and CBS13's Brandi Hitt's report is bookended by unsourced claims that "some people in the U.S. say the 'Border Experience' this [sic] might help people illegally cross the border." ${ }^{14}$ But, as Alexander Zaitchik remarks in his coverage of the night walk,

[T] he charge of preparing migrants for their journey mirrors one frequently leveled against Mexico City in Washington: that the Mexican government tolerates and even encourages migration north because it is one of the Mexican economy's three pillars (the others being oil and the maquiladora factories along Mexico's northern border). Mexicans living in the U.S. send more than $\$ 25$ billion in annual remittances to their relatives south of the 
border. After oil exports, this money constitutes the country's second largest stream of foreign revenue. ${ }^{15}$

Putting aside Washington's failure to acknowledge its own complicity in incentivizing migration through the American economy's dependency on Mexican labor, this charge also has members of the Hñahñu wondering if their form of self-actualization is perceived, ironically, as a threat not merely to this cherished source of foreign revenue, but precisely due to the autonomy it fosters. As Alfonso Martínez (or Poncho, as he is called within the community) asserts,

The worst criticism, I'm sorry to say, has come from the state government from our State of Hidalgo . . . They are the ones who have said that we train people so they can leave. But we don't train them to leave, but so they can stay and work harder here and create the necessary conditions so that we can be selfsufficient. But the government doesn't like that, because when the people are developed and organized, they can't be manipulated. ${ }^{16}$

Within the State of Hidalgo, the night walk has come under further criticism for trivializing the plight of illegal migrants, despite being positioned explicitly on the park's website as an homage to those who have perished on their way to the border. Furthermore, as I will examine shortly, the rousing speeches to tourists at the outset of the walk also frame the experience emphatically as a tribute, not as a trivialization. ${ }^{17}$ The caminata is, needless to say, a controversial and divisive subject, as I experienced firsthand over a dinner conversation in the home of a middle-class family in Mexico City. The daughter, a government employee, read her mother's eagerness to participate in the night walk as an expression of solidarity with the event's implicit critique of the Mexican government, as the daughter sees it, and its failure to provide for its citizens. But as Jose, my coyote, explains, ninety percent of the community migrated to the US prior to the formation of the Parque EcoAlberto, and within four years of the park's operation that percentage changed drastically to thirty percent. ${ }^{18}$ These figures speak to the accomplishments of the enterprising Hñahñu who managed to reverse the fate of their former ghost town, which had like most rural communities in Mexico perished along with their agricultural livelihoods due to low commodity prices under NAFTA and government welfare policies rather than production support. ${ }^{19}$

The popularity of Parque EcoAlberto's night walk - both as a tourist destination and as a media magnet — can be attributed to its positioning on the vanguard of emergent forms of tourism that employ immersive simulations to take participants through an experiential journey, such as the "Escape from U.S.S.R." prison break offered to tourists in the former Soviet military town of Karosta in Latvia, the 
experience of gulag life under Stalinism offered at Grutas Park in Lithuania, and the Underground Railroad reenactment in Indiana, in which tourists play fugitive slaves on the run, to name but a few. ${ }^{20}$ These sites are notable not only for their performative modes of engagement, but also for the ways in which they converse with the burgeoning discourse of "dark tourism." Indeed, one of the first questions that is asked of me when I detail the night walk adventure in El Alberto is, "Why would anyone willingly undergo that?" Scholars of dark tourism, such as Jacqueline Wilson, Richard Sharpley, Philip Stone, John Lennon, and Malcolm Foley are interested in answering this question and exploring the curious drive of tourists to visit sites of suffering, crisis, and devastation. El Alberto's night walk might best be described as representing a nascent form of immersive dark tourism, in which tourists undergo scenarios of social conflict and struggle bodily and experientially, an experience that allows the hardships of the "oppressed other" to inhabit the tourist's imaginative space. This imaginative approximation might help to explain, in part, why tourists are attracted to these forms of immersive dark tourism. More broadly, these phenomena feed into what Jim Butcher describes as the "New Moral Tourism" industry, marked by a distinct "code of utilitarian pleasure" in which the success of the vacation is evaluated by what has been accomplished- "what did we learn, what spiritual or emotional breakthroughs were achieved, what new sensations were experienced?"'21 Night walk participant Rosa Estrada of Mexico City captures the drive of the New Moral Tourist when she reflects on why she has returned to experience the journey for her third time: "We get so immersed in our lives that we forget how much other people suffer." 22 But there is also a distinct form of "political pleasure" derived from the embodied and imaginative approximations immersive dark tourism affords, which I hope my own firsthand accounts of this journey in these pages unfurl. ${ }^{23}$

In my second of two trips down to take part in the border crossing in August 2009 , the park is celebrating its fifth anniversary of the night walk and the aggressive promotion of the event has attracted over two hundred participants. As we wait for events to begin, I gather through casual conversation that many members of the group seem genuinely uninformed about what, exactly, the night walk entails: the fifth anniversary event had, after all, been advertised in the metros of Mexico City as simply that - a "night walk" in amongst other offerings: ziplines, hot springs, rock climbing, kayaking - at what is generally billed as an adventure park. The mostly middle-class Mexicans gathered here had come, as some expressed, eager to test their endurance and get some exercise in this weekend getaway from the dense, urban streets of Mexico City. What, then, were these unsuspecting and comparatively affluent Mexicans thinking as they were taken in open pickup trucks to the first site of our night walk: the front of the sixteenth-century church dedicated to San Alberto from whom the town takes its name? We gather here in a circle, making a provisional stage space on the dusty ground where our principal 
guide, or pollero, appears. Poncho, whose full name is Alfonso Martinez, appears in the uniform balaclava worn by all of our guides - an homage to the Zapatistas' Subcomandante Marcos whose political philosophy undergirds this reenactment (his appearance igniting chants of "Marcos! Marcos!" among the crowd gathered) — and begins a speech that makes evident the political and spiritual motivations behind this caminata nocturna. ${ }^{24}$ Poncho situates the walk in the context of the lived, historical reality of the Hñahñu - a self-designated name in their own language which they have reclaimed in resistance to the more generalized, colonial usage of "otomí" in castellano." 25 The Hñahñu is a community that has reclaimed its identity in the wake of colonial — and neo-colonial — erasure through this reenactment that pays tribute to those who have suffered or perished on the way to reach el sueño Americano ("the American dream"). As Mexico's fifth largest indigenous group with one of the highest percentages of out-migration to the US, the night walk is framed as an opportunity to share the traditions that unite the Hñahñu as a community, including the experience of migration itself, now an indelible part of the traditions reconstituting the Hñahñu in a transnational context. ${ }^{26}$

From Poncho's transtemporal and transnational vision, the duration of this night walk is not limited to the five or so hours we run through the wilderness. In Bergsonian terms, the reenactment inaugurates an anterior past: a past inserting itself in this present and instantiating future conditions of possibility both for the indigenous community and by extension the event's participants, a duration that allows the past to be laid out before the community to be figured anew. Poncho makes clear that we are taking part in the writing and rewriting of history: "We want to do what very few people have done: strengthen the fraternity among people to change this cursed history." We are, he says, heading toward the border, not the literal border that lies some seven hundred miles away from where we stand, but a metaphoric, fictional border that divides humankind from one other. Poncho is a moving orator, attempting to animate and galvanize the participants, who are soon shouting their commitment to the task ahead and chanting the Mexican anthem at the top of their lungs as two volunteers stand holding the Mexican flag, which they have taken from Poncho's backpack, high above the ground; everyone's emotions are at a pitch. But to what degree is Poncho's speech serving as a political performative, an injunction to the mostly middle-class participants from Mexico City from the "wholly other" - an indigenous community which has been effectively displaced not only from their own towns, but also from Mexico's project of modernity? ${ }^{27}$ And what are they thinking as they find themselves subject to this injunction, having arrived under the auspices of an adventure weekend-some with water bottles, hiking boots, and headlamps — where they are being interpellated by the other to make their own histories, their own fears continuous with the Hñahñu, allowing the other to inhabit their imaginative space? Through this injunction, Poncho rhetorically positions this reenactment as an instantiation of Hñahñu identity and 
those of its participants as coterminous, and, in turn, as Tamara Underiner argues, stakes "simultaneous claims to indigenous particularity and Mexican national citizenship." 28

This opening ceremony abruptly concludes to shouting coming from all directions_-“Corran!” "La patrulla!” "Agáchense!" ("Hurry! Run! The border patrol!" "Get down!") with the sounds of sirens approaching in the distance. Soon we are in the throes of this reenactment running blindly and wildly through rugged terrain in the dead of night, trying to discern bodies from maguey cacti, ducking from the sound of gunshots as we emerge from sewer tunnels, soaking our feet in swampy passages, sliding down hillsides, and seeking cover out-of-breath under bushes from the flares of patrol lights. I am interpolated experientially and bodily by this scenario and placed "within its frame"; I have little time to catch my breath or step outside and find my critical footing. As in Diana Taylor's formulation in The Archive and the Repertoire, this scenario "precludes a certain kind of distancing" and exposes the fantasy of ethnography that attempts to "observe cultures from the margins," raising the questions, where am I "here" and what is my "role" here? ${ }^{29}$ The physical demands of the terrain, which force me to duck, crawl, run, slide, and crouch for cover, and the coyote, who shouts at me to hurry and keep pace, become the external duress that constrains me to the role. The immediate exigencies of this exercise do not allow me to "sit cozily," as Underiner says, in "our preexisting notions of subaltern subjectivity." ${ }^{30}$ Rather, the geography inscribes me physically and thinks itself through me, so that regardless of whether or not I am intentionally consigned to this role, I undergo it. If not "subaltern subjectivity," then, what is undergone?

This reenactment is a ritual passage that dramatizes or proposes how the "imaginary borders of cultural identities," as Alicia Arrizón refers to them, are phenomenally and symbolically inscribed on bodies. ${ }^{31}$ As a scenario that consigns its participants to undergo the journey, it proposes a praxis grounded in an understanding of fronteriza/o, or border identities, as an embodied paradigm that is processual and formed in and through movement. In one respect, the praxis of this night walk concedes to Gonzalez's concern about constructing cultural identities in the image of a "symbol of demarcation and exclusion." 32 Borders, as Poncho reminds us at the beginning of our journey, belong to us as the very thing we are trying to get away from, and, as the journey itself reminds us, the border inscribes itself on our bodies. We cannot cross the border or transcend borders anymore than we can quit our own bodies. But as an embodied paradigm, fronteriza/o identity is formed in movement through and across lines that shift under discursive acts of national identity formation and redefinition, and in its movement it undermines the fixity of borderlines, exposing the constitution of these lines as performative acts in and of themselves. As a praxis, the border crossing reenactment brings to center stage once more the movements, operations, exchanges, and stories that have 
constituted the frontiers that define geographical spaces, but which, as Michel de Certeau argues, have been pushed away historically "into the wings" of the " theatre" (as one used to call atlases)," or the map, what de Certeau calls a "totalizing stage on which elements of diverse origin are brought together to form the tableau of a 'state' of geographical knowledge." 33 If "space is a practiced place," as de Certeau asserts, then the diegetic practice of this border crossing reenactment brings to the fore the practices that produce space, exposing the illusory fixity of the map and its frontiers: "What the map cuts up, the story cuts across." 34

After inching across a narrow ledge with a steep drop into the dark waters of the Tula River below, I blindly reach out for an arm to cling to as we lurch across a rocky path. As I get to know the man who belongs to the arm I grabbed hold of in the darkness, I learn that he had actually crossed the border to Arizona some five years prior to his participation in this fictional border crossing. When I ask him why he is participating in this reenactment having experienced an actual border crossing himself, he replies that it was a defining event in his life that he felt was important to commemorate. I wonder in that moment if his participation in this reenactment isn't a means of redressing the trauma of his actual crossing as a symbolic rite of passage through ritual repetition. His participation in this reenacted migrant crossing as a migrant himself has taken on a symbolic significance, reflecting an affirmation of this "life defining" event as defined in movement, in passage. Framed as a ritualized practice, the reenactment presents itself as an opportunity to be attendant upon figurative and imaginative space as it is encountered in and shaped by fronteriza/o identities. We may think of the border as an inherently violent ideality, as Gonzalez reminds us - an abstract cartographic mapping of space that fixes lines, pitting two ideals against one another. But this reenactment belies the myth of this abstract, Euclidean space as preceding the body that encounters it. Rather, the reenactment reminds us that understanding fronteriza/o identities as an embodied paradigm means conceiving of the ways in which the body opens up a figurative space as it moves - a space that belongs to the movement and to the self alone, recuperating movement from the stigma of transience that consigns the migrant to a citizenless subject without rights. This reenacted border crossing proposes a praxis that allows us to attend to the ways in which theorizing the embodiment of fronterizidad suggests a re-imagining of space - a praxis that allows us to address and possibly circumvent Gonzalez's concern about constituting identities under the symbolic weight of the border.

But where is the tourist in relation to fronterizidad, and to return to the question posed earlier, if not "subaltern subjectivity," then what is undergone in this border crossing reenactment? If we think of the body's generativity in space in this embodied paradigm, we must ask how this inflects the kind of imaginative approximation occupied by the tourist-migrant interpellated by this reenactment. The tourist-migrant hailed by this bodily movement through space continues 
along a path of inquiry opened up by Eve Kosofsky Sedgwick's notion of the "periperformative," a conceptual rethinking of the performative that attempts to spatialize and localize notions of performativity while also attempting to "make room for talking about performative affectivity." ${ }^{35}$ Periperformatives, in Sedgwick's formulation, are "lodged in a metaphorics of space." They are not just about performatives "in a referential sense," but rather, "they cluster around them, they are near them or next to them or crowding against them; they are in the neighbourhood of the performative." 36 Being "near" or "next to" offers a way of localizing oneself prepositionally that suggests an ethics of engagement in not presuming to occupy the space of the migrant other, or presuming to know the experience of migration after this simulated experience of migration. ${ }^{37}$ The proximity of being in relation to - and being beside - the experience is what allows the other to inhabit my imaginative space, but because I am beside the experience, my distance from it is only re-entrenched. The periperformative is, in the context of this border crossing reenactment, a form of ethical ek-stasis, of being displaced outside of oneself in order to re-conceive the self in imaginative proximity to another.

The ek-static periperformative that subtends the experience without colonizing it is, arguably, what produces the reenactment's distinct form of political pleasure. It consigns the participant of the Hñahñu's border crossing to take responsibility for and acknowledge the "affective transaction" of the imaginative approximation, insisting "that affect is replayed through us, and is not forgotten or denied." 38 Bodies are brought into affective contact with one another through this proximity as a means of reaching the political ends desired by the Hñahñu, namely, to dissolve the metaphoric and fictional borders that divide humankind from one another (to echo Poncho's opening remarks in the form of a refrain). But this proximity also serves to expose what de Certeau calls "a paradox of the frontier: created by contacts, the point of differentiation between the two bodies are also their common points .... Of two bodies in contact, which one possesses the frontier that distinguishes them?" 39 The embodied paradigm of fronterizidad is not limited to the experience of the transnational identities in movement that live and think across borders; it also presents a way of understanding the thresholds and proximities that open up a relation between one's self and another.

Beyond this, this fictional border crossing in El Alberto also serves to expose broader fictions: the fiction of a regulated border which, as Alicia Schmidt Camacho argues, "has long sanctioned the violent conversion of poor, working-class, and exiled peoples into peoples without a place" and what she calls "the constitutive fiction of U.S. national formation" which excludes from its spheres of citizenship the very labor force without which it could not subsist. ${ }^{40}$ It is, perhaps, these broader fictions that have engendered so many border performances and performances of fronterizidad, as the oeuvres of Guillermo Gómez-Peña and Guillermo Verdecchia demonstrate. But more specifically in this context, I think about the migrant 
performances that preceded those of the tourist-migrants in El Alberto, which took place in the 1970s by Manny Lopez, Tony Puente, and Richard Madina, members of the San Diego Police Department. In the "no-where-land" of the San DiegoTijuana border, police officers infiltrated the border disguised as migrants in order to stop the crime sprees against defenseless migrants heading north. Memorialized in pulp fiction writer Joseph Wambaugh's first nonfiction work Lines and Shadows, the book recounts the officers' studious attempts to inhabit the role of migrant in order to serve as undetectable decoys ${ }^{41}$ The "Border Crime Task Force" occupied an area just north of the border - or the "invisible line" as Wambaugh calls it— "on U.S. soil, in the no-man's-land tacitly relinquished to them by the United States government, which had decided that its border patrolmen would avoid these few square miles of miserable earth and wait farther north, on more accessible land." ${ }^{42}$ The book documents the officers' internal struggles as they attempt to embody the role such that the more convincingly they approximated the role of migrant, the more distantiated they became from it — a recognition, perhaps, of the thresholds that circumscribe the periperformative and determine its ethical relations. While it might be argued that these bodily and imaginative encounters re-entrench the thresholds that constitute border identities - or identities conceived along borders - they also have the potential to dehabituate the border thinking that constitutes these thresholds and expose them as such, namely, as constitutive and performative fictions.

The reenacted border crossing in El Alberto is the community's own constitutive - and restorative - fiction, a narrative underscored in the final leg of our journey. "We're asking you to trust us," a coyote says as we are blindfolded and taken in the back of pickup trucks to our final destination. "We have taken away your sight because we want you to discover the Mexico that exists but that we cannot see," she says. The migratory journey, as the coyote's words make clear, has the potential to reveal what remains unseen in a vision of nation and identity obscured by the abstracted space defined by borders. Instead, this reenactment demonstrates how the embodied experience of migratory movement opens up and extends into a landscape that now offers itself as a figurative space. The landscape is revivified as something that we do, that we undergo, no longer abstracted but made, and it is the migratory journeys in transit through this landscape that have made the lived, transnational histories of the Hñahñu flesh. When we remove the blindfolds, we discover that we have been taken back to where we startedthe central administrative offices, restaurant, and campgrounds of the Parque EcoAlberto - only it is night and the mountainsides that surround us have been lit with torches. It is a spectacular sight to behold, a visual tribute to the local conditions of possibility made visible through a reenactment that has turned the crisis of migration into ritual - a ritual that will hopefully, as our guide Jose tells me, reduce migration to an optional right, rather than a necessity. 


\section{Notes}

1. I would like to thank Tamara Underiner, whose insights along our journey to and from the site have profoundly shaped my thinking about this project. I am also indebted to Rajiv Kaushik for his invaluable commentary on several iterations of this paper and Alicia Schmidt Camacho for her warm reception to my work at the 2010 American Studies Association conference. Camacho's remarkable book Migrant Imaginaries: Latino Cultural Politics in the U.S.-Mexico Borderlands (New York: New York UP, 2008) proved to be an indispensible resource for this article.

2. Karla Garduno, "Regresar a México: La Última Opción," El Siglo de Torreón, 14 December 2008, Web, 22 October $2009<\mathrm{http}$ ://www.elsiglodetorreon.com.mx/noticia/400994.regresar-a-mexicola-ultima-opcion.html>.

3. Marcial Gonzalez, "A Marxist Critique of Borderlands Postmodernism: Adorno's Negative Dialectics and Chicano Cultural Criticism," Left of the Color Line: Race, Radicalism, and Modern Literature in the United States (Chapel Hill: U of North Carolina P, 2003), 295. Interrogating the construction of cultural identities has been the tradition in borderlands theory from Gloria Anzaldúa on.

4. See Charles Taylor's Modern Social Imaginaries (London: Duke UP, 2004), in particular Chapter 2, for an elaboration of a "social imaginary." My use of critical realism here is informed by the work of Tobin Nellhaus, who assesses how the philosophy of critical realism (best exemplified in the work of Roy Bhaskar) can serve as a framework for the analysis of performance strategies. Critical realism takes account of the self-reflexive selection, organization, and synthesis of cultural practices based on image schemas derived from the lived, embodied social experiences of the participants. Image schemas are cultural formations dependent upon social relationships and often acquire a dominant function in determining performance strategies for social action and social change. See Nellhaus's "Critical Realism and Performance Strategies," Staging Philosophy: Intersections of Theater, Performance, and Philosophy (Ann Arbor: U of Michigan P, 2006), 57-84.

5. I am alluding here to the strategies employed in Boal's Theatre of the Oppressed, which stress the importance of "knowing the body" in order to develop an awareness of "bodily possibilities" dehabituated from routine occupations and movements. Exercises encouraging "muscular alienation" also, by extension, foster an understanding of the ways in which power not only inscribes itself on the body, but also how positions of power are inhabited - and inhabitable - social constructions, contingent upon those who cede and are subject to power. But the basic role-playing that takes place in this simulation, in which community members take on the role of border patrol, for example, is also loosely evocative of Boal's Forum Theatre, which acts as a "rehearsal for reality," allowing community members to investigate the conditions of possibility for a social problem or crisis from multiple vantage points. For more information, see Augusto Boal's Theatre of the Oppressed (London: Pluto, 1979).

6. The park's christening in American news reports as a "border crossing theme park" may, to some, make the idea of the site strangely evocative of the "third world theme park" Guillermo Verdecchia's alter ego, Wideload, proposes in Fronteras Americanas (Toronto: Coach House, 1993) 25.

7. Tourist-migrants are also captured by border patrol if they are splintered from the group for various reasons. In my first experience of the caminata in February 2009, my companion was unable to keep up with the run due to an ankle injury. She and her husband were "arrested" and taken to a border patrol van where they spent the remainder of the evening. They were released for the final "act" of the border crossing, so that they could witness the closing moments.

8. Jose Perez Cruz, personal interview, 7 February 2009.

9. Though a tenuous thought-form at the moment, the border crossing reenactment represents, to me, an ingenious form of mimetic subterfuge from within, in the sense that it reenacts the very social crisis responsible for the decimation of the community through iterations that not only have material impacts on the community but provide a means of constituting Hñahñu identity and tradition anew. Examples of this form of mimetic subterfuge from within are richly documented in the opening chapters of Diana Taylor's The Archive and the Repertoire. But a visual emblem of this dynamic can be found in the sixteenth-century frescos of the local cathedral of San Miguel Arcángel in Ixmiquilpan in which a discernibly coherent narrative of indigenous mythology was imbedded within the otherwise Christian imagery dictated to the indigenous painters by the missionaries. For a study of these frescoes, see David Charles Wright Carr's "Zidada Hyadi, el venerado padre Sol en la parroquia de Ixmiquilpan, Hidalgo," Arqueología Mexicana 13.73 (May-June 2005): 39-45.

10. I use ritual here as Victor Turner defines it, as an experience that takes participants through a preliminal, liminal, and postliminal development, that has both evident material impacts on the 
community and, it is hoped, affective impacts on its participants (see Turner's The Ritual Process: Structure and Anti-Structure [Chicago: Aldine, 1969]).

11. This phrase, of course, alludes to the social and economic conditions that necessitate illegal migration north. In the context of her analysis of the Bracero Program of 1942 to 1964, Alicia Schmidt Camacho evokes labor organizer Ernesto Galarza's phrase that "migration was a failure of roots." See Camacho's introduction to Migrant Imaginaries: Latino Cultural Politics in the U.S.-Mexico Borderlands (New York: New York UP, 2008) 1-17.

12. It should be noted that Hñahñu women occupy a central position in the economic development of El Alberto, while many of their husbands and sons are working in the US. Through the Women United cooperative (Mujeres Reunidas) over two hundred women make sponges out of maguey fiber that are purchased by The Body Shop, Inc. and sold in stores throughout Europe and the US. For more on the women's cooperatives and the system of faenas see Ella Schmidt and María Crummett's "Heritage Re-Created: Hidalguenses in the United States and Mexico" (Indigenous Mexican Migrants in the U.S. [La Jolla: Centre for U.S.-Mexican Studies, 2004] 410-12).

13. Personal communication with the author, 15 August 2009.

14. Graciela Moreno, "EXCLUSIVE: Border Crossing Training Ground or Vacation Destination?" ABC30.com, 1 June 2007, Web, 22 August $2010<$ http://abclocal.go.com/kfsn/story?section=news/ local\&id=5269816>; Brandi Hitt, "CBS13 Investigates: The Night Border Crossing Tour," CBS13.com, 27 April 2007, Web, 22 August 2010 <http://cbs13.com/seenon/Border.Patrol.experience.2.477275. html>.

15. Alexander Zaitchik, "Alien World: How Treacherous Border Crossing Became a Theme Park," Reason.com, February 2009, 22 August $2010<$ http://reason.com/archives/2009/01/08/alien-world>.

16. Alfonso Martínez's comments about the perceptions of the caminata conclude a recent documentary titled, "Illegal Border Crossing Theme Park," 1 February 2010, Web, 10 August 2010 $<$ www.vbs.tv/watch/the-vice-guide-to-travel/illegal-border-crossing-park\#>.

17. In the VBS documentary, "Illegal Border Crossing Theme Park," Martínez also alludes to opinions held by members of Hidalgo's state government that the simulation is, in his words, "making fun of migrants." In my first trip down to the site, our coyote's opening remarks before the journey seemed preoccupied with the task of addressing these criticisms from within Hidalgo itself in a way that did not characterize the opening remarks that prefaced my second experience of the caminata. The difference in points of emphasis might be explained by the fact that the opening speech likely changes depending on the coyote introducing the caminata and that my second journey down was framed by the celebrations and optimism that accompanied the fifth anniversary commemoration of the night walk.

18. Jose Perez Cruz, personal interview, 7 February 2009.

19. On the impact of NAFTA on indigenous communities in Mexico, see Jonathan Fox and Gaspar Rivera-Salgado, "Building Civil Society among Indigenous Migrants," Indigenous Mexican Migrants in the U.S. (La Jolla: Centre for U.S.-Mexican Studies, 2004), 2-5. Fox and Rivera-Salgado argue that the government's "rural development strategy has been based on the assumption that a large portion of the rural poor would move either to the cities or to the United States" (3).

20. For an analysis of the Underground Railroad reenactment, as well as a detailed analysis of the caminata nocturna in the broader context of the tourism industry, see Scott Magelssen's "Tourist Performance in the Twenty-First Century" (Enacting History, eds. Scott Magelssen and Rhona Justice Malloy [Tuscaloosa: U of Alabama P, 2011]).

21. D. Brooks quoted in Jim Butcher, The Moralisation of Tourism: Sun, Sand . . and Saving the World? (London: Routledge, 2003) 23.

22. Quoted in Sara Miller Llana, "Mexicans Cross 'the Border'-At a Theme Park," The Christian Science Monitor, 21 February 2007, Web, 15 August $2010<$ http://www.csmonitor.com/2007/0221/ p01s04-woam.html>.

23. My thanks to Elin Diamond for this evocative phrase and her useful comments in response to an earlier version of this paper that was presented at the opening panel of the American Society of Theatre Research's 2009 conference in Puerto Rico.

24. For this observation concerning the influence of Subcomandante Marcos on the Hñahñu of El Alberto, I am indebted to Tamara Underiner who accompanied me on my second journey to El Alberto and who shared a number of insights derived from her own lengthy interviews with Poncho.

25. On this point see David Charles Wright Carr's "Precisiones sobre el término 'otomí", (Arqueologia Mexicana 12.73 [2005]: 19). Carr asserts that "Algunos otomíes prefieren nombrarse en sus proprias lenguas, en parte porque sienten que la palabra 'otomí' [...] ha sido asociada a un estereotipo despectivo en algunos textos novohispanos y modernos" ("Some otomi prefer to name themselves in their own language, in part because they feel that the word 'otomí' has been associated with negative stereotypes in early colonial and modern texts") (19). 
26. Ella Schmidt and María Crummet, "Heritage Re-Created: Hidalguenses in the United States and Mexico," Indigenous Mexican Migration in the U.S., eds. Jonathan Fox and Gaspar Rivera-Salgado (La Jolla, California: Centre for U.S.-Mexican Studies, 2004), 407. According to Schmidt and Crummet, "By 2000, Hidalgo had emerged as the state with the second highest rate of growth of out-migration from Mexico the United States" (403).

27. For an illuminating analysis of the political performative and its possibilities, see J. Hillis Miller's "Performativity as Performance/Performativity as Speech Act: Derrida's Special Theory of Performativity," South Atlantic Quarterly 106.2 (Spring 2007): 231-35.

28. Tamara Underiner, "Playing at Border-Crossing in a Mexican Indigenous Community. Seriously," TDR (forthcoming) 25.

29. Diana Taylor, The Archive and the Repertoire: Performing Cultural Memory in the Americas (Durham: Duke UP, 2003) 32.

30. Underiner 41.

31. Alicia Arrizón, Queering Mestizaje: Transculturation and Performance (Ann Arbor: U of Michigan P, 2006) 17.

32. Gonzalez 295.

33. Michel de Certeau, The Practice of Everyday Life (Berkeley: U of California P, 1984) 121.

34. 129.

35. Eve Kosofsky Sedgwick, Touching Feeling: Affect, Pedagogy, Performativity (London: Duke UP, 2003) 68.

36. 68 .

37. Though he does not examine Sedgwick's notion of the periperformative specifically, I find James Thompson's reflections on Sedgwick's prepositional modes of engagement useful here, especially as it impacts "an ethics of the position of inquiry"; see Thompson's Performance Affects: Applied Theatre and the End of Effect (New York: Palgrave Macmillan, 2009) 132-35.

38. 133.

39. de Certeau, The Practice of Everyday Life 127.

40. Alicia Schmidt Camacho, Migrant Imaginaries: Latino Cultural Politics in the U.S.-Mexico Borderlands (New York: New York UP, 2008) 2, 11-12.

41. My thanks to Anthony Alvarez (no relation) for bringing this book to my attention and informing me about a documentary currently in progress about this unusual task force: $<$ www. thelastofthegunslingers.com>.

42. Joseph Wambaugh, Lines and Shadows (New York: Bantam, 1984) 35. 
